\title{
CORRESPONDENCE
}

\section{MEDICAL TREATMENT OF CATARACT}

To the Editor of The British Journal OF Ophthalmology

SIR,-Since reporting my cases of spontaneous absorption of cataract I have observed one more. Mr. G. Victor Miller's very interesting confirmatory cases will help much in showing up the truth. I think we are able now to put my theory on to a firmer basis : that degeneration and regeneration are at work. At the extremely interesting slit-lamp course at Oxford at Christmas I had the privilege of learning from Mr. Harrison Butler's lucid lectures and lantern slide projections of his pictures drawn from actual cases, as from Dr. Franceschetti's direct messages of Prof. Vogt's investigations, that one form of degeneration and restitution can actually be studied with the slit-lamp. I refer to those cases, where certain lacunae or fluid-gaps form in the cortex near the capsule, and are seen to disappear. Such pathological processes, taking place within the area of the pupil, would affect vision for the worse. Then closing up, it would improve. We must not say that, because medical treatment so far is very unconvincing, it can never be otherwise. It is conceivable that therapeutic remedies will be found whose efficacy in promoting restitution will prove to be above suspicion.

Yours faithfully,

GeORGE Young.

Colchester.

January 15, 1925.

\section{OBITUARY NOTICE}

SIR ANDERSON CRITCHETT, BART., K.C.V.O., F.R.C.S.E. Surgeon-Oculist to the King.

THE death of Sir Anderson Critchett on Monday, February 9, removes from the ranks of British ophthalmologists one of its best known and best loved figures. For years he has been looked up to and respected as the doyen of eye surgeons, and he has filled with distinction every post of honour which his colleagues could confer on him. For close on a century the name of Critchett has been associated with ophthalmic surgery. His father, George 